\title{
A model for detection of early replication bands in cultured fish
}

\author{
J Lobillo, JV Delgado, J Alonso, A Rodero \\ Facultad de Veterinaria, Universitad de Córdoba, \\ Departamento de Genética, Avda Medina Azahara, 9, 14005 Córdoba, Spain \\ (Proceedings of the 9th European Colloquium on Cytogenetics of Domestic Animals; \\ Toulouse-Auzeville, 10-13 July 1990)
}

\begin{abstract}
R-banding / bromodeoxyuridine / acridine orange / fluorescence plus Giemsa (FPG)-staining / fish
\end{abstract}

\section{INTRODUCTION}

Since the first attempts to obtain banding patterns in human chromosomes by means of differential staining after incorporation of bromodeoxyuridine (BrdU) (Latt 1973; Dutrillaux and Lejeune, 1973), other authors have employed this technique to obtain R-and G-bands in mammalian chromosomes.

At present, the BrdU techniques are commonly used because of their high sensitivity in the detection of DNA replication and because of their more resolutive banding patterns.

Obtaining such patterns in fish chromosomes using BrdU methodology has not been tried very often. Using trypsin and BrdU incorporation, Lingyun (1986) obtained the G-banding pattern in Monopterus albus. Delany and Bloom (1984) established R-banding patterns in Salmo gairdneri, and Giles et al (1988) did the same in Scorpaenids.

The present paper describes a model for detection of R-bands in Rutilus alburnoides (Teleosteens, Cyprinidae), using BrdU methodology, and the modified techniques of Delany and Bloom (1984) and Giles et al (1988).

The technique we developed has two experimental phases. In the first, the cell cycle duration is estimated by means of the calculation of the half-BrdU treatment time in which the maximum number of M2 metaphase cells (cells that have undergone two rounds of replication in the presence of $\mathrm{BrdU}$ ) is reached. In the second phase, two different experimental approaches are used to obtain R-bands by means of the incorporation of BrdU during the late period of the DNA synthesis phase. 


\section{MATERIALS AND METHODS}

The cell cycle duration was calculated according to Klingerman et al (1984), using the following experimental conditions: a dose of $0.8 \mathrm{mg}$ of BrdU per gram of fish and a temperature of $25-27^{\circ} \mathrm{C}$.

Two experimental approaches were used to obtain R-bands. First the modified method of Giles et al (1988): $48 \mathrm{~h}$ before sacrifice, fish were injected ip with $0.5 \mathrm{mg}$ of phytohemagglutinin-M (PHA-M) per $50 \mathrm{~g}$ of body weight; 1 injection of $0.8 \mathrm{mg}$ of $\mathrm{BrdU} / \mathrm{g}$ of fish was administered $53 / 4,5$ or $41 / 4 \mathrm{~h}$ before sacrifice (just at the time of the last cell cycle); $2 \mathrm{~h}$ before sacrifice fish were injected ip with $0.2 \mu \mathrm{g}$ of colchicine per gram of fish.

Second, the modified version of the Delany and Bloom (1984) method: one injection of PHA-M $48 \mathrm{~h}$ before sacrifice; 3 injections of BrdU were given, 18, 14 and $10 \mathrm{~h}$ before sacrifice during the penultimate cell cycle; 1 injection of colchicine $8 \mathrm{~h}$ before sacrifice.

After sacrifice, the cephalic kidney was removed, macerated and maintained in a solution of $0.075 \mathrm{M} \mathrm{KCl}$ for $90 \mathrm{~min}$. After this time, the cellular suspension was washed and fixed in acetic acid-methanol (1:3), and metaphase plates were prepared using the air-dried technique. Metaphase plates were stained with acridine orange (Dutrillaux and Lejeune, 1973).

\section{RESULTS}

Rutilus alburnoides, under the experimental conditions described above showed a cell cycle of $8 \mathrm{~h}$.

With the modified Giles' technique, treatment with BrdU for $53 / 4 \mathrm{~h}$ before sacrifice resulted in a maximum percentage of $\mathrm{R}$-banded metaphases (45\%). Thus, $53 / 4$ hours is the length of time from the mid-DNA synthesis phase to the metaphase, for the majority of the cell population.

The modified technique of Delany and Bloom resulted in $65 \%$ banded metaphases. An R-banded metaphase cell, stained with acridine orange, is shown in figure 1.

\section{DISCUSSION}

It is well established that, in mammal chromosomes, there is a clear relation between $\mathrm{R}$-bands (early replicating bands) and G-bands (late replicating bands). In fish, the results obtained by Lingyun (1986) also seem to corroborate this relation between $\mathrm{G}$ and $\mathrm{R}$ chromosome bands and an order in DNA replication.

The successful preparation of R-banding patterns in $R$ alburnoides could lead us to conclude that, in fish cells (Delany and Bloom, 1984; Lingyun 1986; Giles et al, 1988), a temporal organization for replication exists, consisting of alternate early and late replicons, as is observed in other eukaryotic cells (Latt, 1976; Sumner, 1982).

The approach used to obtain $\mathrm{R}$ chromosome banding gave positive results. It shows that a high percentage of cells, between $45 \%$ (modified technique of Giles et $a l, 1988$ ) and $65 \%$ (modified technique of Delany and Bloom, 1984), incorporated BrdU during the mid-to-late $\mathrm{S}$ period, which expresses the R-banding pattern. 


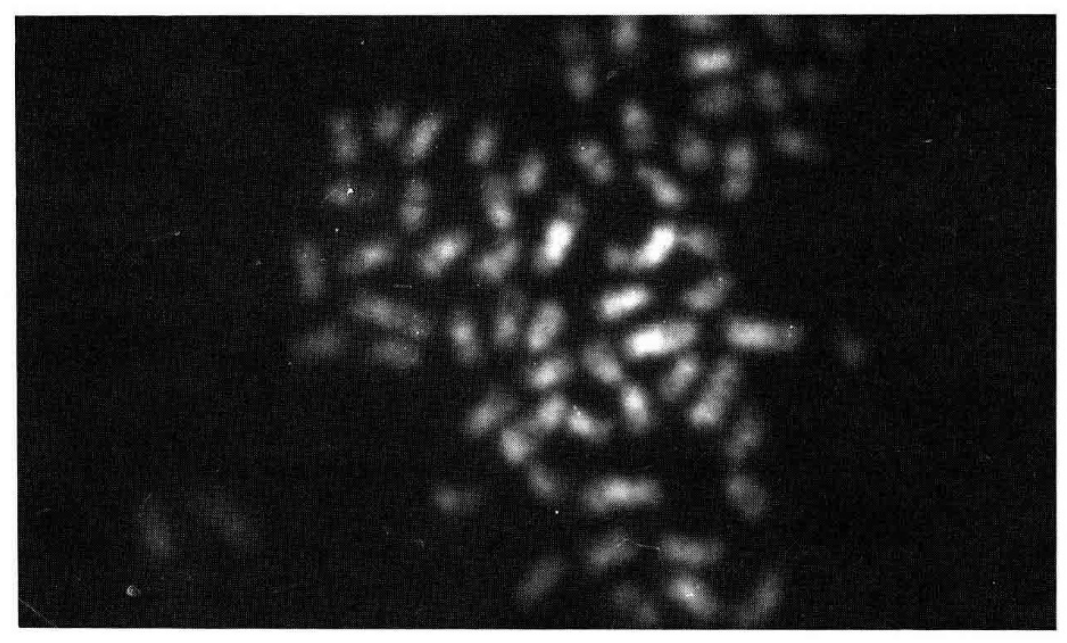

Fig 1. R-banded metaphase cell of Rutilus alburnoides.

Dark areas in the chromosome correspond to late-replicating DNA and light ones to early-replicating DNA.

The approach based on the modified method of Delany and Bloom (1984) shows a greater percentage of $\mathrm{R}$-banded metaphases. We suspect that this method, under our experimental conditions, is better adapted to the asynchronic character of the cell population.

The R-banding pattern obtained by the BrdU method will enable progress to be made in the chromosomal characterization and karyotype analysis in fish. R-banding techniques in fish are essential because the attempts to obtain complementary Gbands have been unsuccessful (Delany and Bloom, 1984).

\section{REFERENCES}

Delany ME, Blocm SE (1984) Replication banding patterns in the chromosomes of the rainbow trout. $J$ Hered $75,431-434$

Dutrillaux B, Lejeune J (1973) Coloration des chromosomes humains par l'acridine orange après traitement par le 5-bromodésoxyuridine. CR Acad Sci Paris Ser D, 3179-3180

Giles V, Thode G, Alvarez MC (1988) Early replication bands in two scorpion fishes (order Scorpaeniformes). Cytogenet Cell Genet 47, 80-83

Klingerman AD, Bishop WE, Valentine LC (1984). Use of the mudminnow, Umbra sp, in an in vivo sister chromatid exchange test. Natl Cancer Inst Monogr 65, 111-118

Latt SA (1973) Microfluorometric analysis of DNA synthesis in human metaphase chromosomes. Proc Natl Acad Sci USA 70, 3395-3399

Latt SA (1976) Longitudinal and lateral differentiation of metaphase chromosomes based on the detection of DNA synthesis by fluorescence microscopy. In: Chromosomes Today. (Pearson PL, Lewis KR, eds) John Wiley \& Sons, Inc, New York

Lingyun L (1986) Studies on making fish chromosomes elongated with high resolution G-banding. Indo-Pacific Fish Biol Icthyological Society of Japan, Tokyo, 910-917

Sumner AT (1982) The nature and mechanism of chromosome banding. Cancer Genet Cytogenet 6, 59-88 